\title{
Kissing the earth' scene in Pashedu Tomb
}

\author{
Doha M Sami Abdel Hamid \\ Higher institute for Tourism, Hotels and Computer-Seyouf-Alexandria
}

\begin{abstract}
The scribe'Pashedu' lived during the reign of King Seti I and King Ramses II,he had the titles: "Servant in the Place of truth on the west of Thebes" and "Scribe in the Place of truth". His Tomb is located in Deir el Medina Necropolis on the West Bank at Luxor, dating to the early years of Ramses II's reign, it was decorated with one of the best known scenes in Thebes Necropolis ,the scene of :"kissing the earth".

The kneeling ritual was also one of the daily rituals in Temples ${ }^{i}$, when the high Priest enters the sanctuary, he kisses the ground with the face down, this ritual was called: $r A$ sn tA $i w ~ H r m H r i$ :kissing the ground with the face down ${ }^{\mathrm{iii}}$.

This paper attempts to discuss the concept of kneeling and bowing down in Ancient Egyptian religious beliefs, by analyzing Pashedu tomb's scene at Deir el-Medina, to display different studies concerning this scene, who may reflect an act of praying or drinking water.
\end{abstract}

\section{Introduction}

The famous scene in Pashedu Tomb shows the scribe 'Pashedu' kneeling and bowing down beneath a dom-palm tree ; this scene was also represented in others tombs in Deir El Medina Necropolis, like the tomb of the scribe 'Irynefer'.

The Egyptian equivalent term of "sn $t A$ " or "proskynese" literally means :'kissing or smelling

\section{bon-t3 $10 \div$} the earth, ${ }^{\text {,iv }}$,it may be preceded by the term' $k s$ ': which means "bowing",or the term $d w z$ ntr:meaning: "worshipping God" "The term"sn $t A$ " was firstly mention in spell 755b of the Pyramids texts:"The souls come to thee bowing ;they kiss the earth at thy feet","wich whas also mentioned in Old Kingdom biography to describe an act of obeisance ,when the king tells an official :"Don't kiss the earth ;kiss my foot".

The term sn $t A$ :kissing the earth , was sometimes replaced by the term :"dhn $t_{3}$ ", ground"(with the forehead) ${ }^{\text {vii }}$,recalling the Islamic pray ${ }^{\text {viii }}$.

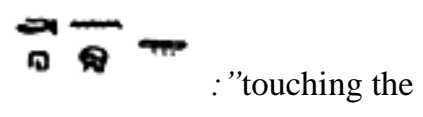

The Archeological site of Deir el-Medina, is located in a desert valley on the west bank of Luxor ${ }^{\mathrm{ix}}$, in a small desert valley behind the Qurnet Murai hill slope .A Bàcs discussed Qurnet Murai burials and concluded that :'The burials of this site indicate that loyalty to a ruler could overwrite professional association" "The site burials were located in a center place (fig1) ,between the Ramsseum temple and Medinat Habu ${ }^{\mathrm{xi}}$. Deir el-Medina was excavated by an Italian expedition from Turin from1905-1906 and in 1909, a German expedition in 1913, and since1917 has been excavated and published by the French Institute in Cairo ${ }^{\text {xii }}$.

\section{Deir el Medina}

Deir el Medina is an Arabic name meaning : "Monastery of the Town", which refers to a Coptic settlement with a church and monastery situated in the earlier town of " $p_{3} d m i "$, which means : the town ${ }^{\text {xiii }}$, also the village and its Necropolis were known as" "st mAat" ,meaning: the place of Goddess Maat, place of truth ${ }^{\text {xiv }}$. The modern name of Deir el-Medina is also referring to the Ancient Egyptian workmen's village in which the tomb builders of the Kings lived with their families ${ }^{\mathrm{xv}}$. During the New Kingdom, Deir el Medina was the settlement of the workmen responsible for the construction and decoration of the royal tombs in the valley of the Kings and valley of the Queens ${ }^{\text {xvi }}$. The first settlement and community of workmen in Deir el Medina was probably founded in the reign of ThutmosesI ${ }^{\text {xii }}$, and was expanded during the nineteenth and twentieth Dynasties ${ }^{\text {xviii }}$ when number of workmen was increasing in line with royal tomb dimensions ${ }^{\text {xix }}$.

The community at Deir el-Medina consisted of the workers and craftsmen who were employed in the construction of the New Kingdom royal tombs, Maspero suggests that the workers of Deir el-Medina were a kind of religious community who maintained the cults of kings who were buried at Thebes ${ }^{\mathrm{xx}}$. Royal tomb artisans throughout the Egyptian new Kingdom considered Deir el- Medina as their eternal home ${ }^{\mathrm{xxi}}$. The site was of particular interest and unique in what it reveals and provides evidence of daily lives of artisans and workmen ${ }^{\text {xiii }}$; it was conceived as sacred 
ground. Tombs were built there as early as the Middle Kingdom and a village settlement housing the royal-tomb builders was founded on the site in the early New Kingdom ${ }^{\text {xiii }}$.

The workmen's village gradually became surrounded by chapels and temples. Although the settlement was abandoned by the end of the New Kingdom, the site was still used for burials and for religious devotion ${ }^{\text {xxiv }}$.

During the Ptolemaic Period a sandstone temple dedicated to the goddess Hathor was built there, a small chapel was added to this temple in Roman era; the Copts later converted the temple into a church and a monastery, to which the Arabic name of the site refers. Ruins of numerous small chapels and temples of various types are located around the northern part of the village settlement dating to the $18^{\text {th }}$ Dynasty $^{\mathrm{xxv}}$.

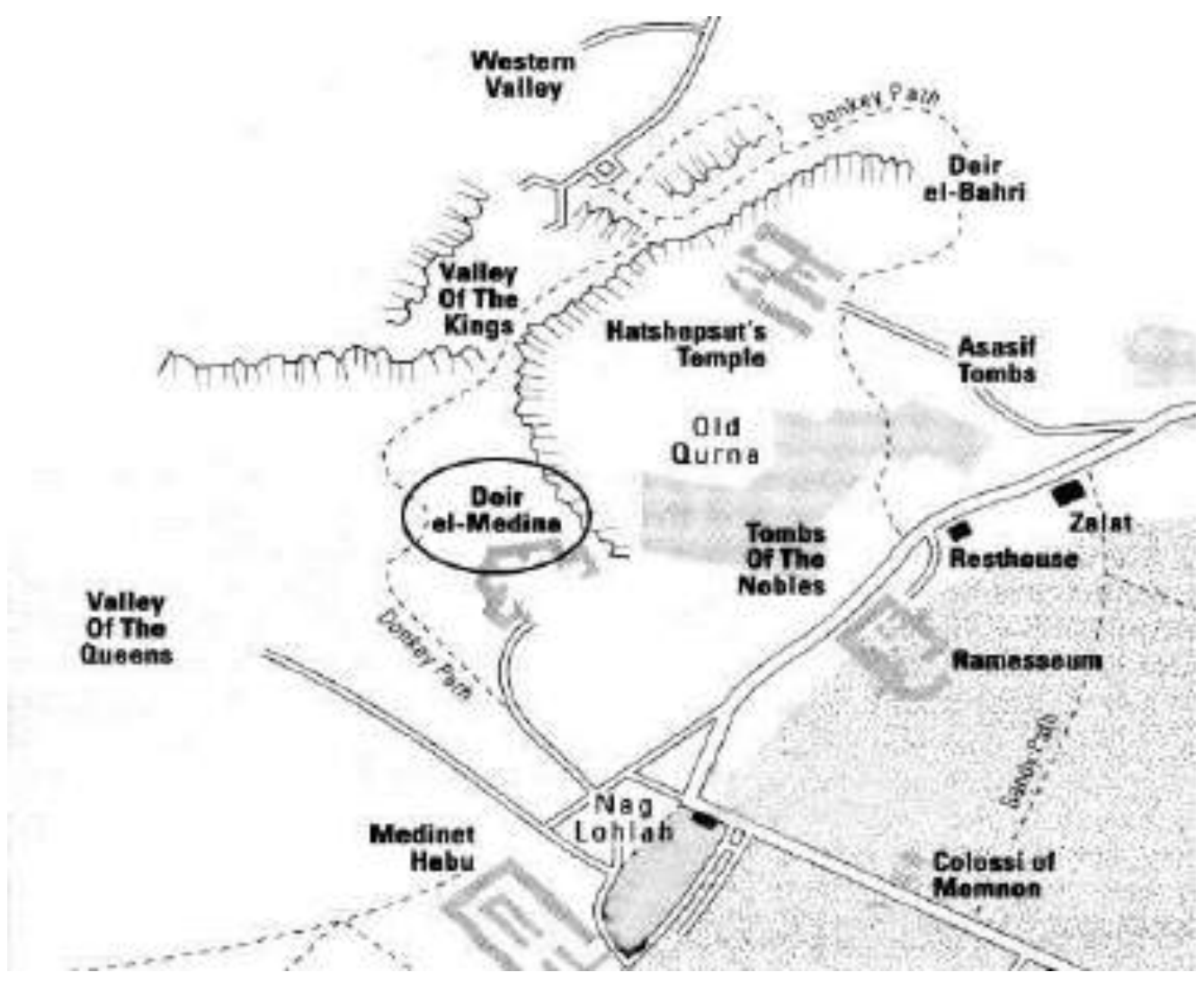

Fig.1 Deir el Medinam: Vladimera, Introduction to Deir El Medina: www.webkatalog.sk < Home < Lectures, last accessed1/5/2014.

\section{The cemetery}

The craftsmen's cemetery was located on the lower part of the hill that rose to the west of the village. It had fifty-three decorated tombs, forty of which dated to the New Kingdom ${ }^{\text {xxvi }}$.

The tomb architecture was mostly comprised with an underground vault, a chapel topped by a small pyramid, at the apex of which was a carved pyramidion symbolizing the rising sun ${ }^{\text {xxvii }}$. The chapel had several chambers and was decorated with scenes and funerary texts from the Book of the Dead ${ }^{\text {xxviii }}$.

\section{Pashedu Tomb}

The tomb (T3) was among the numbered tombs of Deir el Medina Necropolis ${ }^{\text {xxix }}$, it was firstly mentioned by Robert Hay in 1834 during the reign of Ibrahim Pasha, Mohamed Ali's son. The number and diversity of finds from the site is remarkable; besides ruins of houses, chapels, and temples, and hundreds of tombs, some of which were found intact $^{\mathrm{xxx}}$.Pashedu's Tomb was discovered in a perfect condition, there were no traces of any Arab or Copt occupation, the fragments of the sarcophagus and the paintings on the walls were very distinguished ${ }^{\mathrm{xxxi}}$.

It was one of the tombs that were intact, it was a simple tomb layout with an antechamber and a short corridor leading to a burial chamber, only the corridor and 


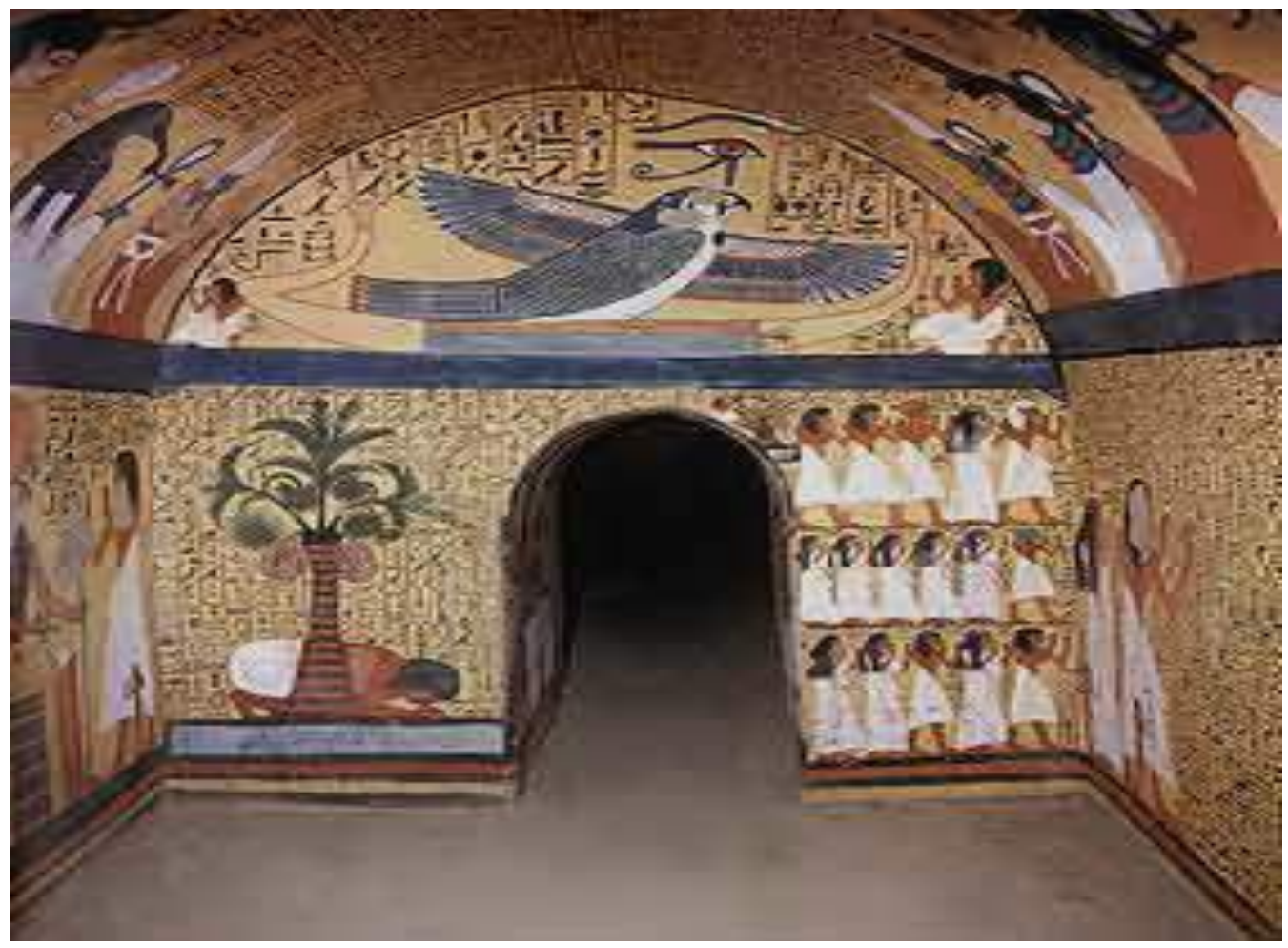

Fig2.Pashedu tomb: www.pinterest.com/ljyl/archeology.

burial chamber were decorated. The walls were decorated with scenes and texts from the book of the dead ${ }^{\mathrm{xxxi}}$,the tomb was also characterized by a vaulted ceiling topped with the $w \underline{d} 3 . t$ "'eye xxxiii, this basic division of the vaulted ceiling and walls, with panels of equal size divided by text bands, recalls the identical arrangement found in other burial chambers during the Ramesside tombs at Deir el-Medina. Whereas these were clearly intended to imitate the decorative layout and scheme of sarcophagi that earned them the name of 'sarcophagus vault ${ }^{\text {xxiv }}$.

\section{Pashedu}

Pashedu

Place of Truth on the west of Thebes"xxxvi "Scribe in the place of truth"xxxvii .His father Menna

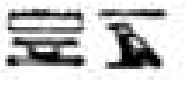
apparently worked for the Temple of God Amon on the East bank ${ }^{\text {xxxviii }}$. Pashedu would have probably been the first member of his family to work with the community at Deir El Medina ${ }^{\text {xxix }}$.Members of his family his mother :Huy

\section{$=912^{3}$}

, and his wife: Nezmebehdet

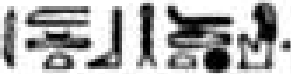

${ }^{x 1}$. Pashedu refers to himself as a 'scribe of the Tomb' in a number of graffiti .He bears the title of " the scribe of the mansion of the gods and the Lords of the West" in some other graffiti ${ }^{x l}$. He might even have been a smdt-scribe who, on occasion, assumed the responsibility attached to the office of the 'senior' scribe ${ }^{\text {xlii }}$. According to Černy, Pashedu was : 'scribe in the Place of Truth', as mentioned in Ostraca of Strassburg H 108, 6, whilst the scribe Pashedu commemorated the arrival of the inundation in an Ostraca dating to the 3rd month of Akhet, day 20, of a year 4 of the reign of RamessesIII ${ }^{\text {xliii }}$.McDowell discussing Pashedu's career favors the suggestion that his duties were more akin to the responsibilities held by a scribe of the vizier than those of a scribe of the tomb administration ${ }^{\text {xliv }}$.

\section{Pashedu scene}

The famous scene of pashedu, is located at the top of the eastern wall near to the entrance ${ }^{\mathrm{xlv}}$. The image on the left records two corner scenes; the scene on the right comes from the left front wall of the burial chamber, it is one of the best known scenes in Thebes ${ }^{\text {xlvi }}$.This scene shows the scribe Pashedu kneeling and bowing down beneath a domepalm tree against a backdrop of crisp black hieroglyphs. ${ }^{\text {xlvii }}$. 
There are twenty one columns of Hieroglyphics texts around him(fig.3), derived from the book of the dead coming from chapter $62^{\text {xlviii }}$, Chapter for Drinking Water in God's Domain ${ }^{\text {xlix }}$.

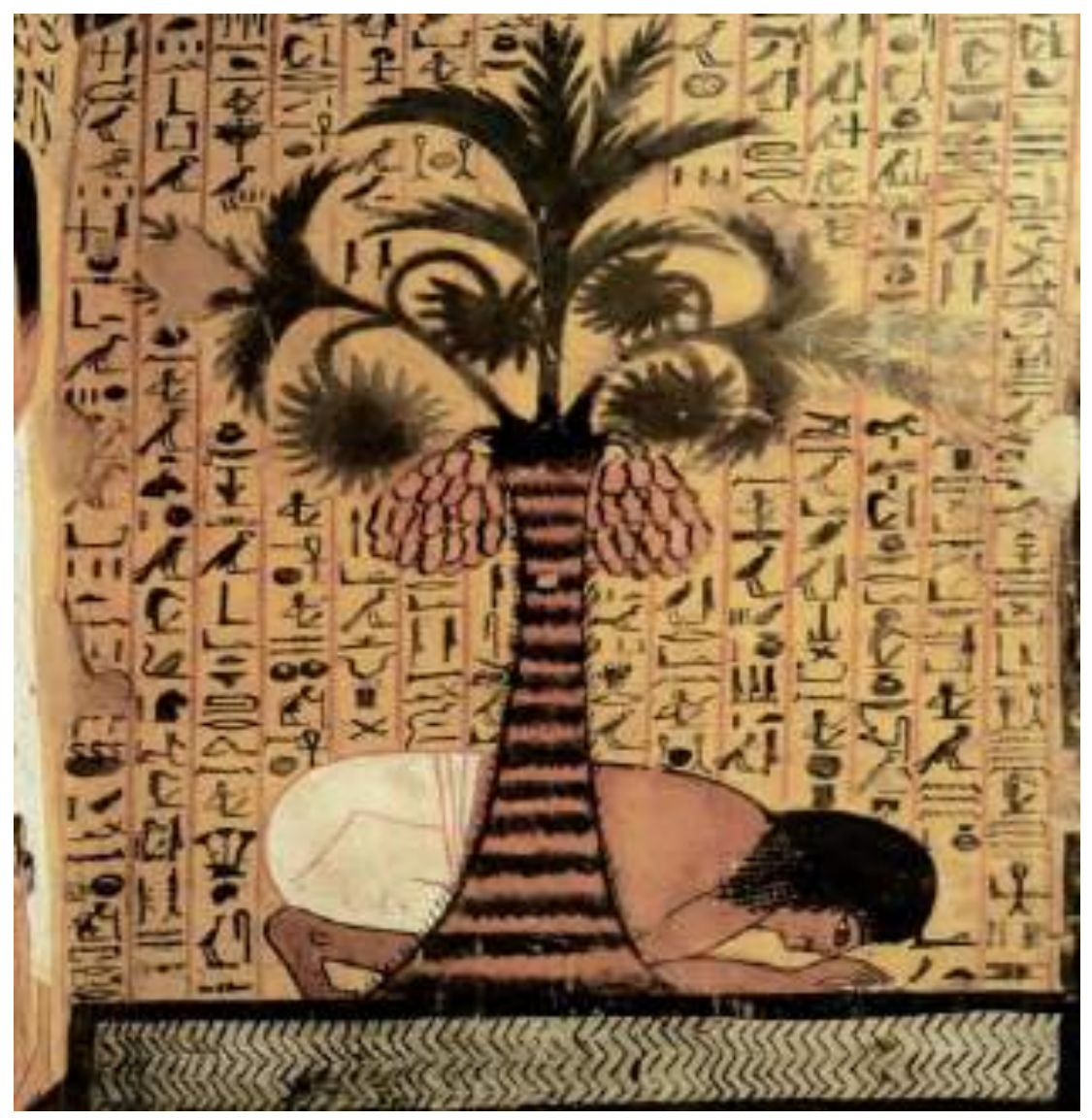

Fig.3:Lesko.L, Pharaoh's workers, Cornell University (1994),p.87.

\section{Analyzing the scene}

This scene was the best known scene in this tomb, which shows Pashedu in the shade of a dome-palm tree or a luscious palm tree according to McDonald and Coupar. The dome- palm tree was one of three kinds of palms cultivated in Ancient Egypt, which was worshipped as a symbol of male strength ${ }^{\text {li }}$,in the same way as the date palm was worshipped as a symbol of femininity ${ }^{\text {lii }}$.

Some studies mentioned that the tomb owner was bending down to take a sip of water to preserve him from harm in the hereafter ${ }^{\text {liii }}$,according to spell 62 of the Book the dead ,spell of drinking water in God's domain ${ }^{\text {liv. }}$ ' Opened for the deluge of Osiris, parted are the celestial waters for Thoth and for the inundation Lord of the horizon for this name of 


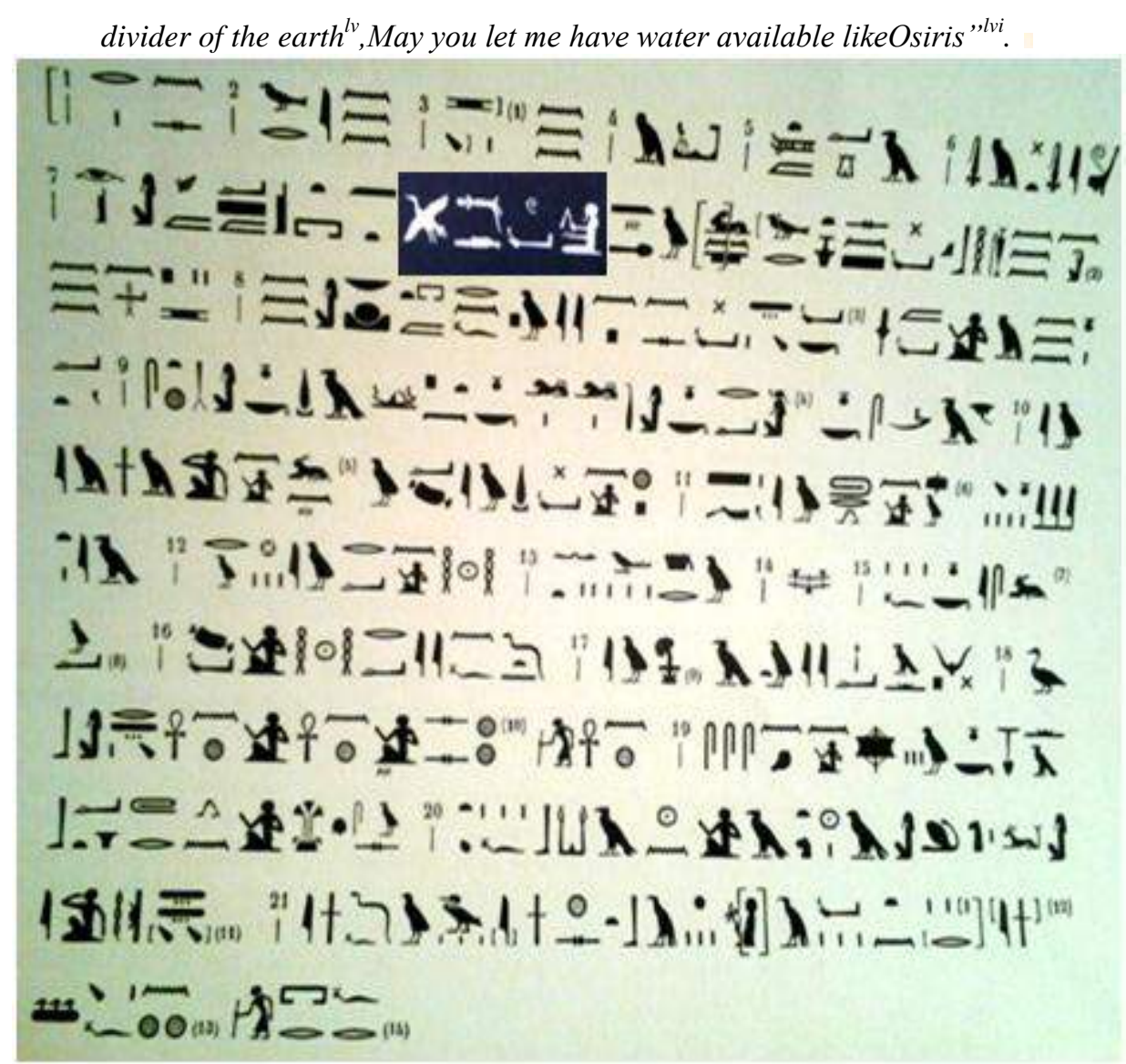

Fig.4: Chapter62 of the book of the dead of the scribe Pashedu,: Zivie.A.P, La tombe de Pached à Deir ElMédineh,N:3, IFAO, TomeXCIX,(1979),p.34.

The Hieroglyphic text in (Fig.4) shows Chapter 62 of the book of the dead, which refers to: "chapter for drinking the water in the Necropolis and not to be harmed by the fire, Pashedu servant in the place of truth" lvii.

Some Egyptologists analyzed the scene as an act of adoration and mentioned that Pashedu was kneeling and bowing down for praying ${ }^{\text {viii }}$, while other studies didn't see any contradiction between bowing in purpose of "praying" and bowing in purpose of "drinking", and analyze the scene as : " prayer for drinking water in the afterlife" lix , while surrounded by religious inscriptions and spells derived from the book of the dead to protect him during his pray ${ }^{\mathrm{lx}}$.

\section{Irynefer's scene}

Irynefer the better preserved tombs of Deir El Medina , and one of the most colorful of the tombs of the craftsmen .

The scene is very similar to Pashedu's scene(table1), this scene is located at the top of the eastern wall near to the entrance, where Irynefer is kneeling before a Dome- palm 


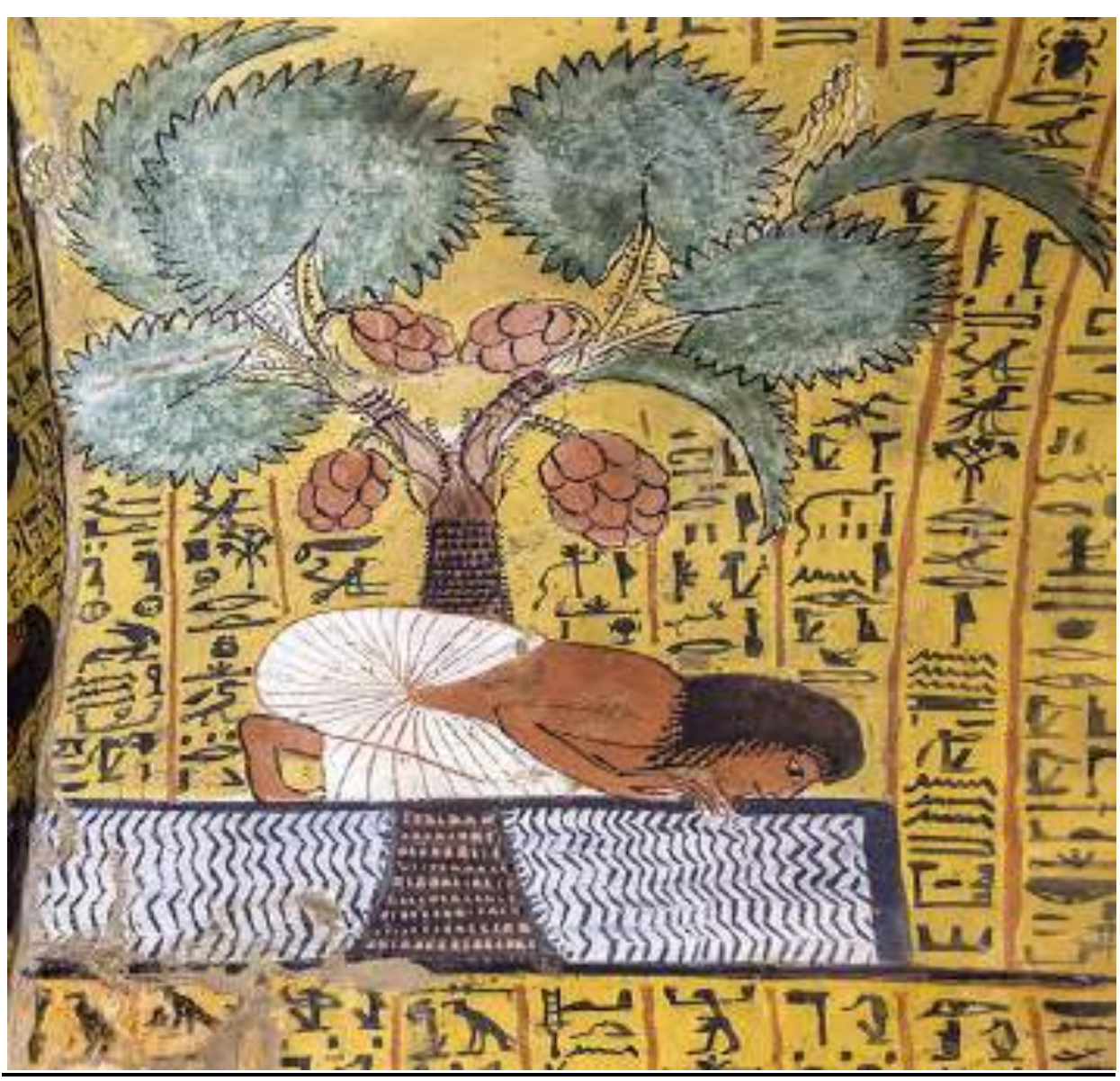

Fig.5:http://www.ifao.egnet.net/bases/archives/bruyere/?id=MS_2004_0144_017

tree, or a palm-tree according to Porter and Moss ${ }^{\text {lxii }}$, drinking from a pool of fresh water (Fig.5) , spell for "drinking water in the necropolis" ,from chapter 62 of the Book of the Dead. 
Comparing Pashedu and Irynefer scenes

\begin{tabular}{|c|c|c|}
\hline & "Pashedu". & "Irynefer". \\
\hline The tomb number. & TT3. & TT 290. \\
\hline Title of the tomb's owner. & Servant in the place of truth. & Servant in the place of truth. \\
\hline The pool. & $\begin{array}{l}\text { The pool was surrounded by } \\
\text { black line showing the earth. }\end{array}$ & $\begin{array}{l}\text { The pool was surrounded by } \\
\text { black line showing the earth. }\end{array}$ \\
\hline The hand. & $\begin{array}{l}\text { The left hand side is shown } \\
\text { instead of the right one. }\end{array}$ & $\begin{array}{l}\text { The left hand side is shown } \\
\text { instead of the right one. }\end{array}$ \\
\hline The kneeling figure. & $\begin{array}{l}\text { Pashedu is kneeling behind } \\
\text { the Dom-palm tree. }\end{array}$ & $\begin{array}{l}\text { Irynefer is kneeling in front of } \\
\text { the Dom-palm tree. }\end{array}$ \\
\hline The Dom-palm tree. & $\begin{array}{l}\text { The roots are not shown. } \\
\text {-Small leaves. }\end{array}$ & $\begin{array}{l}\text { The roots are shown. } \\
\text {-Big leaves. }\end{array}$ \\
\hline The scene location & $\begin{array}{l}\text { At the top of the eastern wall } \\
\text { near to the entrance. }\end{array}$ & $\begin{array}{l}\text { At the top of the eastern wall } \\
\text { near to the entrance. }\end{array}$ \\
\hline
\end{tabular}

Table. 1

\section{Conclusion}

"Kissing the earth scene" in Pashedu tomb was probably represented in order to show a kind of pray or an act of obeisance or adoration, accompanied by spell of chapter 62 of the book of the dead "chapter for drinking the water in the Necropolis" .In spite of the presence of chapter 62,Pashedu was not probably kneeling in purpose of drinking because it's not familiar to drink in a such way, but he was kneeling in order to kiss the holy earth of the underworld or kissing the water of the underworld, that's why the scene was decorated and accompanied by the chapter 62 , chapter of drinking water.

Deir El-Medina tombs were characterized by this kneeling down under a dom-palm tree scenes, which were not represented in Valley of the Kings scenes. Although spells from the book of the dead were represented on walls of valley of the Kings tombs, the scene of "kissing the earth" or "drinking water" was not seen on Kings private tombs. There were a wide variety of religious scenes in royal Theban tombs, but none of them were depicted with the bowing down scenes. This may probably demonstrate that the Kings were manifestations of Gods ,so they were not shown in such an adoration scenes, who may put them equal to workmen and craftsmen ,because kings were afforded by a divine status, and were honored to be : "the embodiment of divine power on earth". We can conclude that this distinguished scene which was inscribed in the same location in Deir el Medina tombs, was specially represented only for workmen and craftsmen tombs, may be to show their adoration to Gods and their obeisance to their Kings. 


\section{منظر "تقبيل الأرض"بمقبرة باشدو فى دير المدينة}

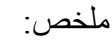

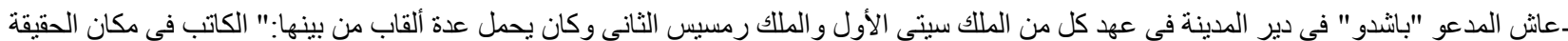

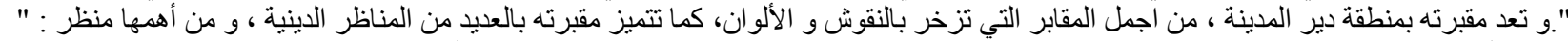

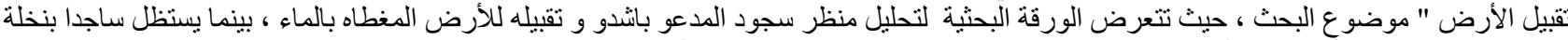

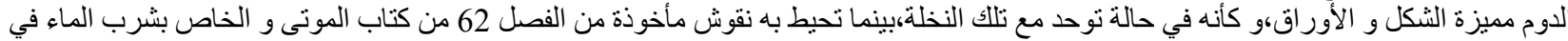
العام الآخر . تتناول تللك الورقة البحثية تحليل لذللك المنظر و بئن فيان لمفهومه الديني.

\section{References}

-A Bàcs.T(2011), The last New Kingdom tomb at Thebes : The end of a great tradition? BMSAES British Museum Studies in Ancient Egypt and Sudan 16.

-Allen.G(1974), The Book of the dead or going forth by day, SAOC Studies in Ancient Oriental Civilization (37),London.

-Allen.G(1960), The Egyptian book of the dead documents in the Oriental Institute Museum at the University of Chicago, The University of Chicago Oriental Institute publications , vol.72.

- Bleiberg.E(1997), Pharaoh's workers: the villagers of Deir el Medina by Lesko, JSTOR,vol(117).

- Brierbrier.M(1995), The Tomb Builders of the Pharaohs, British museum publication.

- Bierbreir.M(2008),Historical Dictionary of Ancient Egypt, $2^{\text {nd }}$ edition,P lymouth,UK.

-Clère.J, Monuments inédits des serviteurs dans la Place de Vérité, BIFAO Bulletin de l'Institut français d'archéologie orientale. 28 (1929).

-Davies.B(1999), Who's who at Deir el Medina, Egyptologische Uitgaven XIII, Leiden.

-Décamps.C(2005), Deir el-Medina in the Days of the Ramesses,Musée du Louvre.

-Fischer.H(1982), Proskynese,LÄIV, col.1125.

-Geddes and Grosset(1997), Ancient Egypt Myth and History,New Larnak.

- Gee.J(2004),Prophets,Initiation and the Egyptian Temple,JSSEA(31).

-Haring.B, (2003)' From oral practice to written record in Ramesside Deir el Medina”, JESHOJournal of the economic and social history of the orient ,Leiden., vol.46,n:3.

- Heffernan.G(2010), Royal images in private Tombs at Thebes in the early Ramesside period,A Thesis submitted for the Master degree,,Institute of Archeology and Antiquity, University of Birmingham.

- Lesko.L(1994), Pharaoh's workers, Cornell University.

-McDonald.A,Coupar.S(2012) The Egyptological afterlife of Colin Campbell. Egyptian Archaeology( 40).

- Meskell.L(1999),Archaeologies of life and death ,JSTOR Journal of the American Research Center in Egypt.,vol.103.

-Mota.S(2012), The Household Religion in ancient Egypt:What do the archaeological evidences tell us? Hathor Studies of Egyptology,vol.1.

-Nigel,Strudwick.H(1999), A Guide to the Tombs and Temples of Ancient Egypt,Thebes in Egypt, British museum press.

-Porter.B,Moss.R(1970), Topographical Bibliography of Ancient Egyptian Hieroglyphic texts ,reliefs, and paintings ,The Theban Necropolis, part1:private tombs, Griffith Institute, Ashmolean Museum, Oxford.

-Romer.J(1984), Daily Lives, Daily life in Egypt of the Pharaohs, New York.

-Strudwick.N(1999), JSTOR,vol.125(2005),p.270 : Cherpion.N,Deux tombes de la XVIII dynastie à Deir el Medina, MIFAO,vol.114,IFAO Institut français d'archéologie orientale.

-Täckholm.V(1977),Flora,LÄ Lexikon Der Ägyptologie (II),Wiesbaden.

-Toivari-viitala.J(2011),Deir-el-Medina development, UCLA Encyclopedia ofEgyptology,University of Helsinki,p.1:http://escholarship.org/uc/item/6kt9m29r,last accessed on :28/4/2014.

-Valbelle.D(1975),” Deir el Medineh”,LÄ Lexikon Der Ägyptologie (I). 
-Weiss.L,(2009),Personal religious practice:House altars at Deir el- Medina ,JEA Journal of Egyptian Archeology 95.

-Wilson.P(2004), Hieroglyphs a very short introduction, Oxford University press.

-Zivie.A.P(1979), La tombe de Pached à Deir El-Médineh,N:3, IFAO Institut français d'archéologie orientale., TomeXCIX.

'Gee.J(2004),Prophets,Initiation and the Egyptian Temple,JSSEA(31),p.99.

ii Ibid.

iii Ibid.

${ }^{\text {iv }}$ Fischer.H, Proskynese,LÄ(IV),(1982),col.1125.

${ }^{\mathrm{v}}$ Ibid,col.1126.

vi Ibid.

vii Ibid.

viii Ibid,col.1127.

ix Valbelle.D," Deir el Medineh",LÄ(I)(1975),col.1028.

${ }^{x}$ A Bàcs.T(2011), The last New Kingdom tomb at Thebes : The end of a great tradition? BMSAES (16),p.9.

${ }^{x i}$ Ibid.

${ }^{x i i}$ Bierbreir.M(2008),Historical Dictionary of Ancient Egypt, $2^{\text {nd }}$ edition,P lymouth,UK,p.60.

xiii Toivari viitala.G,Deir el Medina development, UCLA Encyclopedia of Egyptology Los Angeles(2011),p.1: http://escholarship.org/uc/item/6kt9m29r,last accessed on :28/4/2014.

${ }_{\text {xiv }}$ Clère.J, Monuments inédits des serviteurs dans la Place de Vérité, BIFAO 28 (1929), p. 173.

${ }^{x v}$ Weiss.L, Personal religious practice:House altars at Deir el- Medina,JEA(95)(2009),p.193.

xvi-Haring.B,' From oral practice to written record in Ramesside Deir el Medina", JESHO, vol.46,n:3(2003),p.250.

xvii Strudwick.N, JSTOR,vol.125(2005),p.270 : Cherpion.N ,Deux tombes de la XVIII dynastie à Deir el Medina, MIFAO,vol.114,IFAO(1999),p.124.

xviii Mota.S(2012), The Household Religion in ancient Egypt:What do the archaeological evidences tell us?,Hathor Studies of Egyptology,vol.1,p.39.

${ }^{\text {xix }}$ Meskell.L, Archaeologies of life and death ,JSTOR,vol.103(1999),p.181.

${ }^{x x}$-Heffernan.G(2010),Royal images in private Tombs at Thebes in the early Ramesside period,A Thesis submitted for the Master degree,,Institute of Archeology and Antiquity , University of Birmingham,p.41.

${ }^{x \times i}$ Bleiberg.E, Pharaoh's workers: the villagers of Deir el Medina by Lesko, JSTOR,vol(117)(1997),p.220.

xxii Geddes and Grosset, Ancient Egypt Myth and History,New Larnak(1997),p.349.

xxiii Toivari,op.cit,p.1.

${ }^{\text {xxiv }}$ Ibid.

${ }^{x \times v}$ Nigel,Strudwick.H, A Guide to the Tombs and Temples of Ancient Egypt,Thebes in Egypt, British museum press(1999),p.14.

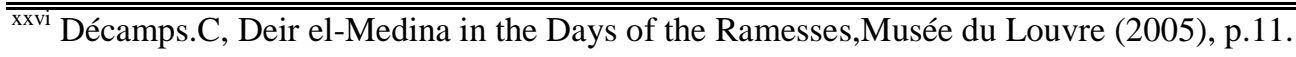

xxvii Ibid.

xxviii Ibid. 
${ }^{\text {xxix }}$ Porter.B,Moss(1970), Topographical Bibliography of Ancient Egyptian Hieroglyph texts ,reliefs, and paintings, The Theban Necropolis, part1:private tombs, Oxford, p.9.

${ }^{\mathrm{xxx}}$ Toivari,op.cit,p.3.

${ }^{x x x i}$ Zivie.A.P, La tombe de Pached à Deir El-Médineh,N:3, IFAO, TomeXCIX,(1979), p.8.

xxxii Porter,Moss,op.cit, p.9.

xxxiii Ibid.

xxxiv A Bàcs,op.cit,p.15.

${ }^{x x x v}$ Brierbrier.M, The Tom - Builders of the Pharaohs, British museum publication (1995), p. 29.

xxxvi Porter,Moss,op.cit, p.9.

xxxvii - Lesko.L, Pharaoh's workers, Cornell University (1994),p.44:

-Romer.J, Daily Lives, Daily life in Egypt of the Pharaohs, New York(1984), p.22.

xxxviii Porter,op.cit,p.9.

xxxix Ibid.

${ }^{\mathrm{xl}}$ Ibid.

${ }^{x l i}$ Davies.B, Who's who at Deir el Medina, Egyptologische Uitgaven XIII, Leiden(1999),p.93.

xlii Ibid.

xliii Ibid.

xliv Ibid.

${ }^{x l v}$ Zivie,op.cit, p.7.

xlvi Ibid.

${ }^{x l v i i}$ McDonald, Angela, and Coupar, Sally Anne (2012) The Egyptological afterlife of Colin Campbell. Egyptian Archaeology, 40 ,p.24.

xlviii Ibid.

xlix Ibid.

I Ibid.

li Täckholm.V(1977),Flora,LÄ(II),Wiesbaden,col.269.

lii Ibid.

liii Porter.B, Topographical Bibliography of Ancient Egyptian Hieroglyphic texts,reliefs, and paintings,part1: The Thebean Necropolis, Oxford(1970), p.10.

liv Allen.G(1974), The Book of the dead or going forth by day,SAOC(37),London,p.55.

Iv Ibid.

Ivi Allen.G, The Egyptian book of the dead documents in the Oriental Institute Museum at the University of Chicago, The University of Chicago Oriental Institute publications, vol.82(1960), p.136.

lvii Zivie, op.cit,p.35.

Iviii Lesko.L, Pharaoh's workers, Cornell University (1994), p.87.

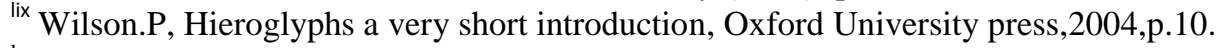

${ }^{\mathrm{lx}}$ Ibid.

Ixi Porter,Mossmop.cit,p.372.

-http://www.ifao.egnet.net/bases/archives/bruyere/.

Ixii Ibid,p.373. 